Railway Engineering

Jan. 2022

Issue:15, Page: 13-29

Review Article

doi: 10.47072/demiryolu. 1018008

http://dergipark.org.tr/demiryolu

e-ISSN: 2687-2463, ISSN: 2149-1607

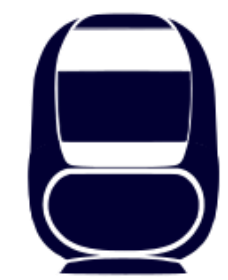

\title{
Dünyadaki Son Gelişmeler Çerçevesinde Yüksek Hızlı Demiryolu Tünel Tasarımı ve Türkiye'deki Durum
}

\author{
Evren POŞLUK \\ İstanbul Üniversitesi - Cerrahpaşa, Mühendislik Fakültesi Jeoloji Mühendisliği Bölümü, \\ Büyükçekmece Yerleşkesi G Blok Kat:2 Büyükçekmece, İstanbul, Türkiye \\ evrenposluk@gmail.com
}

(Alınış/Received: 02.11.2021, Kabul/Accepted: 16.12.2021, Yayımlama/Published: 31.01.2022)

Öz: Yüksek standartlı demiryolları, kat ettiği mesafeler ve içerdiği karmaşık mühendislik yapıları açısından oldukça zorlu imalatlardır. Gerek imalat gerekse işletmecilik faaliyetleri sırasında maliyet etkin olması istenir. Güzergâh çalışmalarından mühendislik yapılarının tasarımına kadar bu durumu etkileyen birçok parametre vardır. Bu çalışmada, yüksek hızlı demiryollarında tünel tasarımı konusuna odaklanmaktadır. Bu amaçla öncelikle yüksek hızlı demiryolu tünel tasarımında kullanılan ana hat ve tünel güvenliği konuları uluslararası standartlar çerçevesinde irdelenmiş, bu konuda dünyada yapılan son çalışmalar derlenmiştir. Ardından Türkiye'de geçmişi yaklaşık 20 yılı bulan yüksek hızlı demiryolu tünel imalat tecrübeleri aktarılmıştır. İlk tasarımından bu yana neredeyse hiç değişmeyen tünel yapısında, işletme sırasında oluşan sorunlar çerçevesinde yapısal ve geometrik iyileştirmeler gerektiği sonucuna varılarak bu kapsamda öneriler sunulmuştur.

Anahtar kelimeler: Tünel, Tünel tasarımı, Yüksek hızlı demiryolu, Tren-tünel aerodinamiği

\section{High Speed Railway Tunnel Design in the Framework of Recent Developments in the World and the Situation in Turkey}

\begin{abstract}
High standard railways are very demanding productions in terms of the distances they cover and the sophisticated engineering structures they contain. It is desired to be cost effective during both manufacturing and management activities. There are many parameters that affect this situation, from route studies to the design of engineering structures. This study focuses on tunnel design in high speed railways. For this purpose, first of all, the main line and tunnel safety issues used in high-speed railway tunnel design were examined within the framework of international standards, and the latest studies in the world on this subject were compiled. Then, the high-speed railway tunnel manufacturing experience in Turkey, which has a history of nearly 20 years, has been conveyed. In the tunnel structure, which has hardly changed since its first design, it was concluded that structural and geometric improvements are needed within the framework of the problems that occurred during operation, and suggestions were presented in this context.
\end{abstract}

Keywords: Tunnel, Tunnel design, High speed rail, Train-tunnel aerodynamics.

\section{Giriş}

Türkiye'de demiryolu serüveni 1866 yılında İzmir-Aydın demiryolu ile başlamış, cumhuriyetin ilk yıllarıyla birlikte ivme kazanmış ardından Sürat Demiryolu Projesi gibi atılımlar planlanıp imalata başlanmış olsa da sonuçlanamamıştır. Modern anlamda ilk Yüksek hızlı demiryolu (YHT) tüneli Ankara-Eskişehir hattında 2006 yılında tamamlanmıştır. Devamında Ankara-Konya ve Köseköy-Gebze arasında 31 farklı tünel (yaklaşık 46 km) işletmeciliğe açılmıştır. Halen AnkaraSivas (test çalışmaları devam etmekte) Bursa-Yenişehir ve Ankara-İzmir hatlarında çalışmalar devam etmektedir.

Yüksek hızlı demiryolları yüksek maliyetli yapılardır. Bu nedenle dünyada ve ülkemizde optimum mühendislik çözümleri için araştırmalar on y1llardır devam etmektedir. Üzerinde en çok 
durulan konuların başında tren-tünel aerodinamiği gelmektedir. Yüksek Hızlı Demiryollarında (YHT) her ne kadar aerodinamik etkiler araç şekli ve yapısal özellikleriyle ilişkili gibi anlaşılsa da trenin açık arazilerde hareketi sırasında bu açıdan büyük sorunlarla karşılaşmaz. Etrafı sınırlandırılmış bölgelerden geçerken aerodinamik etkiler belirginleşir. Bu çalışmada, ülkemizde yaklaşık 20 yıldır değiştirilmeden kullanılan tünel tasarımına odaklanılarak tünel güvenliği, tüneltren aerodinamiği ve işletmecilikte yaşanan sorunlar çerçevesinde tünel tasarımı ve tünel yapısal tedbirlerine odaklanılmıştır.

\section{Demiryolu Tünellerinin Tasarımı}

Demiryolları için inşa edilecek tünelin geometrik yapısı ve iç tasarımı demiryolu güzergâhı için belirlenen hız, işletmecilik türü (yük/yolcu; dizel/elektrik), tünel içerisindeki hat sayısı, tünel uzunluğu, güvenlik ihtiyacı, tünel içerisindeki su varlığı, çeken/çekilen araç aerodinamik yapısı gibi birçok etmene bağlıdır. Bu bölümde demiryollarındaki tünel tasarımı hakkında bilgi verilmiştir.

\subsection{Demiryolu tünellerinde güvenlik}

Demiryolu tünellerinde güvenlik, kaza risklerini veya bu kazaların insanlar ve demiryolu hatları üzerinde yarattığı etkileri azaltarak, kullanıcıya en uygun güvenlik seviyesi sağlamak amacı ile demiryolu tünellerinde ön etüt, proje, inşaat ve işletme aşamasında uygulanacak kriter ve teknik özelliklerdir [1]. Demiryollarında kaza olaylarının meydana gelme olasılığı hala oldukça düşük olarak kabul edilse de uzun tünellerde bu tür olayların olası sonuçları felaket olabilir [2].

Tünelde beklenmeyen durumlar olduğunda mutlaka tahliye sistemlerinin ve tahliye prosedürlerinin önceden hazır olması gereklidir. Demiryolu tünellerinde risk oluşturabilecek durumlar; sıcaklık yaratan olaylar (yangın), soğuk olaylar (deray, çarpışma) ve uzun durma (arıza) şeklinde özetlenebilir. Tünellerde riskler ve önlemlere ilişkin akış şeması Şekil 1'de verilmiştir [1].

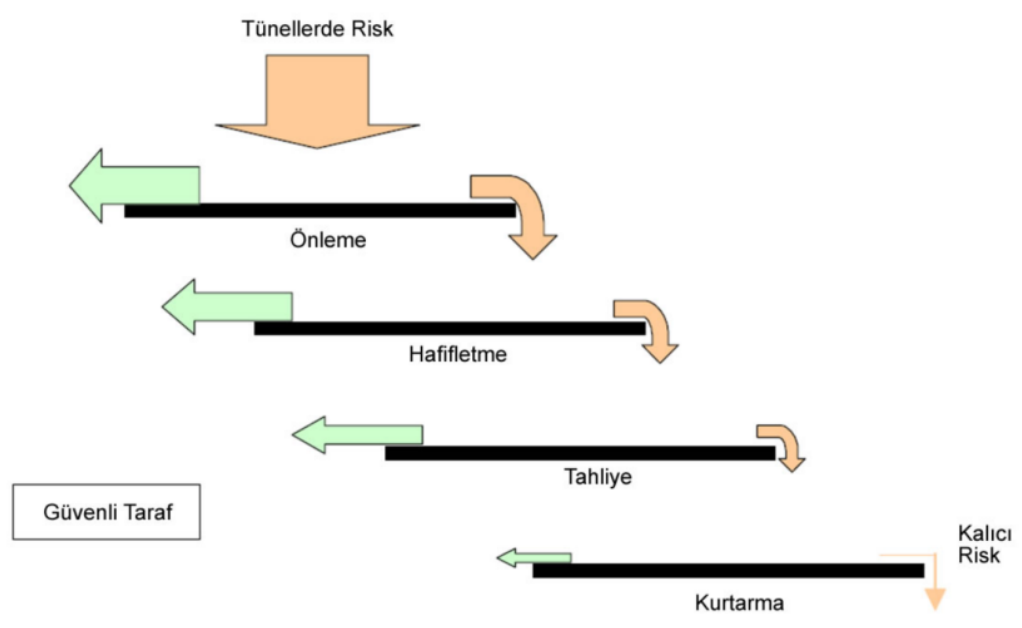

Şekil 1. Demiryolu tünellerinde risk ve tedbirlere yönelik akış şeması [1]

Demiryolu tünellerinde güvenlik önlemleri alt yapı ve tesisat olarak 2 aşamada incelenmektedir. Alt yap1 güvenlik önlemleri, tünelin içerisinde yolcuların en yakın çıkış noktalarına yönlendirilmeleri, çıkış noktalarına ilerleme sırasında sorun yaşamamaları ve çıkış işleminin sorunsuz yapılabilmesi aşamalarını içermektedir [3]. 
Tünel uzunluğuna ve tünel içi hat durumuna göre (tek tüp, çift tüp) kaçış tüneli gereksinimi ve türü değişmektedir. Dünyada ve ülkemizde en çok tercih edilen çift hatl tek tüp tünellerdir. Bu tüneller şayet 1000 m'den uzun ise yapısal güvenlik önlemleri açısından değerlendirilmelidir [1]. $5000 \mathrm{~m}$ uzun tüneller için ise tek tüp yerine çift tüp tercih edilmelidir [2] (Şekil 2). Uzunluğu 20 km'den fazla olan tüneller özel tasarım ve planlama gerektirmektedir [4, 2]. Ek olarak birbirini takip eden (peş peşe) tüneller arasında 500 m'den daha az mesafe varsa veya açık kısımda bir güvenlik bölgesi yoksa her iki tünel tek bir tünel gibi düşünülmelidir [3].

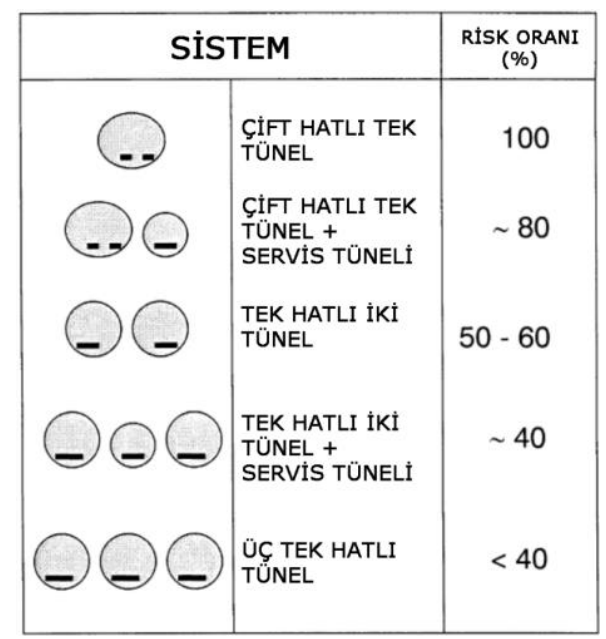

Şekil 2. Tünel tüp çeşidine göre güvenlik seviyeleri [2]

Tünellerde tahliye işleminin yapılabilmesi için tünel içerisinde tahliye yolları ve kaldırımları planlanmalıdır. Tahliye kaldırımları için $75 \mathrm{~cm}$ genişlik; $2,25 \mathrm{~m}$ yükseklik ve en fazla $500 \mathrm{~m}$ yürüyüş mesafesi önerilmektedir [1,4]. Tahliye yolları ise $1000 \mathrm{~m}$ uzun tünellerde düşünülmeli ve yolcunun 500 m'den az yürütecek şekilde tasarlanmalıdır [4]. Yaklaşım tüneli, paralel tünel şaft ve ray altı kaçış tüneli şeklinde tasarlanabilirler. Yaklaşım tünelleri $1000 \mathrm{~m}$ uzun olmamalıdır. Şayet sadece yolcu çıkışı için planlanıyorsa en az 1,50 m genişliğinde ve 2,25 m yüksekliğinde kurtarma hizmetleri için de planlanıyorsa en az 2,25 m genişliğinde ve 2,25 m yüksekliğinde olmalıdır. Şaftlar 30 m'den kısa olmalıdır ve merdivenler minimum 1,2 metre genişliğinde olmalıdır. Tünel içi eğim, araçlara ve yayalara göre ayarlanmalıdır [1].

Bir diğer acil durum tahliye tüneli tipi ise çift hatlı tek tüp TBM tünellerinde uygulanan ray altı emniyet tünelidir (Şekil 3). Poşluk ve Korkanç [3] tarafından ülkemizde ilk defa T-26 tüneli için önerilen bu modelde her 1000 metrede bir merdivenlerle $3 \mathrm{~m}$ genişliğinde ve $2,25 \mathrm{~m}$ yüksekliğinde rayların altında bulunan emniyet tüneline bağlantı sağlanmaktadır. Söz konusu model Eşme-Salihli T-1 tünelinde uygulanmaktadır. 


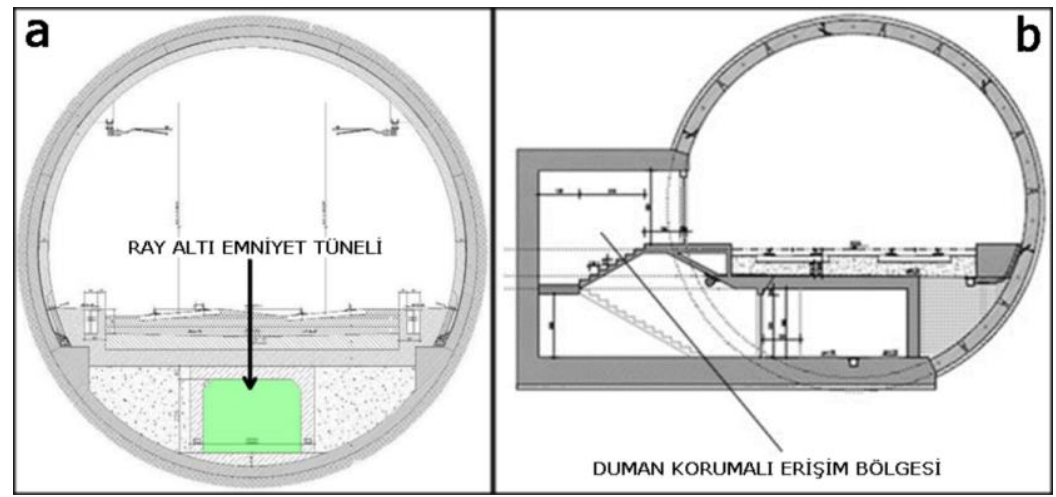

Şekil 3. ray altı emniyet tünel kesitleri (a-ray altı emniyet tüneli, b-ana tünel-ray altı emniyet tüneli bağlantı kesiti; [3])

Alt yapı tedbirleri ile birlikte güvenlik ve işletme sırasında devamlılığın sağlamak amacıyla tesisat tedbirleri de alınmalıdır. EN 50126 [5] göre tünel içerisinde gereken tedbirler; Acil durum 1şıklandırması (500 m uzun tünellerde); tahliye sinyalizasyonu, tünel içi su tesisatı ve makineinsan iletişim sistemleridir.

\subsection{Tünel aerodinamiği}

Tünelden geçen trenlerin neden olduğu aerodinamik problemler, açık havadaki duruma göre daha karmaşık ve ciddidir. Ancak tren hızının düşük olduğunda tünellerdeki aerodinamik etkiler çok belirgin değildir $[6,7,37,46]$. Genellikle bir trenin etrafındaki akış alanının kararsız, türbülanslı ve sıkıştırılabilir olduğu bilinmektedir. $\mathrm{Bu}$ durum; tünel içerisindeki trenin aerodinamik sürtünmesi, kayma akımı, piston etkisi, tünel ve tren içindeki basınç dalgaları, tünel çıkışındaki mikro basınç dalgaları, gürültü ve titreşim vb. kavramlarla ilintilidir (Tablo 1) [8].

Tablo 1. Tünellerde aerodinamik problemler [8]

\begin{tabular}{|c|c|c|}
\hline & & Aerodinamik Problemler \\
\hline 1 & \multirow{5}{*}{$\begin{array}{c}\text { Tünel ve } \\
\text { demiryolu } \\
\text { hattı }\end{array}$} & Hava akışı \\
\hline 2 & & Tünel çıkışında mikro basınç dalgası \\
\hline 3 & & Tünellerde termal ortam, havalandırma çalışması ve yangın önleme \\
\hline 4 & & $\begin{array}{c}\text { Tünellerde basınç dalgalanması, insan konforu ve tünel kesit alanı için tasarım } \\
\text { parametrelerinin belirlenmesi }\end{array}$ \\
\hline 5 & & Tünellerde çalışan ve ekipman güvenliğine piston etkisinin etkisi \\
\hline 6 & \multirow{4}{*}{ Tren } & Aerodinamik sürükleme, tren hızı ve enerji tüketimi \\
\hline 7 & & $\begin{array}{c}\text { Yolcu konforu, tren iç ortamı (basınç değişimi ve klima havalandırması), tren } \\
\text { yüzeyindeki basınç değişimi }\end{array}$ \\
\hline 8 & & Aerodinamik gürültü \\
\hline 9 & & Tren başı ve kuyruğunun aerodinamik özellikleri \\
\hline
\end{tabular}

Piston etkisi: Tren, tünelden geçtiğinde tüneldeki hava tren tarafından sıkıştırılır ve onu takip eder. Negatif basınç bölgesi trenin arkasında oluşur ve dışarıdaki havayı tünele çeker. Bu durum "piston etkisi" olarak tanımlanır [9]. Tünel uzunluğunun azalması piston etkisini artıracak ve tren uzunluğunun ve tren hızının artmasıyla piston etkisi artacaktır [10]. Genel olarak, bir havalandırma şaftı, piston etkisini kontrol etmekte etkilidir ve şaftın konumunu optimize ederek, piston etkisini azaltılabilir [11, 38, 39, 40].

Tüneldeki hava akımı: Tren, tünel gibi sınırlı bir boşluktan geçtiğinde, havanın viskozitesi nedeniyle sınır tabakasının yakınındaki hava trenle birlikte hareket eder ve ortaya çıkan hava 
akımı açık havaya göre daha ciddidir. Tüneldeki trenden kaynaklı hava akımı tüneldeki ekipman ve bakım personeli üzerinde büyük etkisi vardır [8].

Hava akımı hızı tünel uzunluğu, tren uzunluğu ve bunların oranından etkilenmektedir $[15,16]$. Özellikle, hava akımı hızı uzun trenlerle artar. Önemli hız dalgalanmaları esas olarak trenin önünde meydana gelir ve basınç dalgasının genliğinde bir azalma ile zayıflar [12]. Tren kayma akımı tren şeklinden önemli ölçüde etkilenir, Khayrullina vd. [13] çalışmasında, arkası küt şekilli trene sahip yük araçlarının iz yoğunluğunun, akıcı kuyruklu yolcu araçlarınınkinden önemli ölçüde daha yüksek olduğu bulunmuştur (Şekil 4).
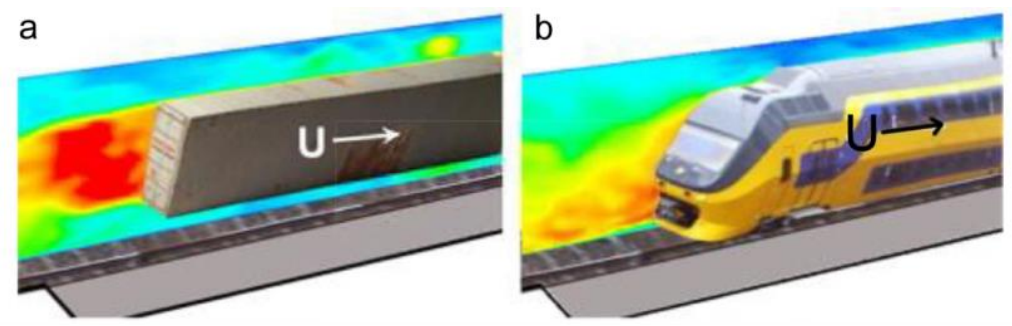

Şekil 4. Bir tünelden geçen trenin simülasyonu: (a) Yük treni (b) Yolcu treni (Tren hareketi:U ok yönündedir [13]

Tüneldeki trenlerin aerodinamik sürüklenmesi: Açık hava ile karşılaştırıldığında, tünel içindeki çalışma ortamı nispeten kapalıdır, bu da trenin önünde ek aerodinamik sürüklenme getiren bir basınç artışına yol açar. Tünelde yayılan basınç dalgası tren etrafındaki basınç dağılımını değiştirecektir, bu nedenle trenin aerodinamik direnci, piston etkisi, kayma akımı ve titreşimi tüneldeki basınç dalgasından açıkça etkilenir $[8,41,42,17]$.

Bazı çalışmalar, aerodinamik sürükleme ile tren burun uzunluğu arasında doğrusal bir ilişki olduğunu öne sürmektedir $[14,15,16,21]$. Tren burun uzunluğunun artmasıyla hem aerodinamik sürüklenme hem de basınç direnci azalır. Toplam basınç direnci 2 m'lik bir burun uzunluğuna kadar hızla azalır; burun uzunluğu 2 m'den uzun olduğunda, sürtünme azalma oranı önemli ölçüde azalır ve burun uzunluğundan bağımsız olarak viskoz sürtünme neredeyse sabittir [16].

Tüneldeki hava akımının neden olduğu tren titreşimi: Tren, tünelin girişine ulaştı̆̆ında tren üzerindeki aerodinamik kuvvetlerin yanal ve dikey dalgalanmaları nispeten büyüktür. Tren açık havadayken yalpalama momentinin küçük olduğunu ve tren tünele girerken yalpalama momentinin aniden arttığı bilinmektedir. Suzuki [17] yaptığı çalışmada çift hatlı tek tüp tünelde iki trenin tünel içerisinde karşılaştığı durumlarda trenin iki tarafi arasında bariz basınç farklılıkları oluştuğunu ve tünelin duvar tarafındaki basınç dalgalanmasının tünel merkez tarafına göre daha şiddetli olduğunu söylemiştir.

Demiryolu tren/tünel sisteminde basınç dalgası: Yüksek hızlarda tren tünele girdiğinde karmaşık bir dalga sistemi üretilir. Tünele trenin burun kısmı girdiğinde ilk sıkıştırma dalgası olarak adlandırılan hızlı bir basınç artışı oluşur. Tren gövdesinin daha fazla girişiyle basınçta hafif bir artış görülür, tren kuyruğu tünele girdiğinde, tünelde basınç düşüşüne yol açan bir sıkıştırma dalgası üretilir. Bu durum tren şekli, tren uzunluğu, trenin hızı, tünel uzunluğu ile doğrudan ilişkilidir [8]. Bunların dışında basınç dalgasının azaltılmasının yolu havalandırma şaftlarıdır. Havalandırma şaftlarının boyutu, sayısı ve konumu basınç dalgası üzerinde bariz bir etkiye sahiptir [18].

Tünel çıkışında mikro basınç dalgası: Tünellerdeki basınç dalgaları tünel çıkışına ulaştı̆̆ında, sıkışma dalgasının bir kısmı genişleme dalgası olarak tünele geri yansır ve diğer kısmı genellikle tünelin dışına saçılmak üzere bir itme gürültüsü oluşturur. İlk sıkıştırma dalgasının neden olduğu gürültü yoğunluğu fazladır ve bir mikro basınç dalgası oluşturur [8]. Liu vd., [20] yaptıkları 
çalışmada mikro basınç dalgasının gücünün tren hızıyla arttığını, düşük frekanslı ve kısa süreli olduğunu, büyüklüğünün yaklaşık olarak tren hızının küpüyle orantılı olduğu söylemektedir.

Mikro basınç dalgasını azaltmak için tren kafasının şekli ve tünel giriş-çıkış yapısını optimize etmek iki ana yöntemdir [15, 21, 47]. Iida vd. [22] optimal burun uzunluğunun 7 m'den fazla olduğunda, maksimum mikro basınç dalgasının parabolik burun şekillerine ve önceden optimize edilmiş burun şekillerine kıyasla \%18-27 ve \%12-19 oranında etkili bir şekilde azaldığını belirtmişlerdir. Tünel giriş-çıkış bölgeleri (flüt yapıları) trenler için ani bir değişim bölgesidir. Bu kısımda sıkıştırma dalgaları, genişleyen dalgalar ve mikro basınç dalgaları gibi birçok karmaşık akış alanı oluşmaktadır. Bazı bilim adamları, tünel girişinde cihazlar kurarak bir tüneldeki basınç dalgasını veya tünel çıkışındaki mikro basınç dalgasını azaltmayı başarmışlardır. Bu çalışmalardan Zhang vd., [23] tarafından yapılan çalışmalar Şekil 5'de gösterilmektedir.
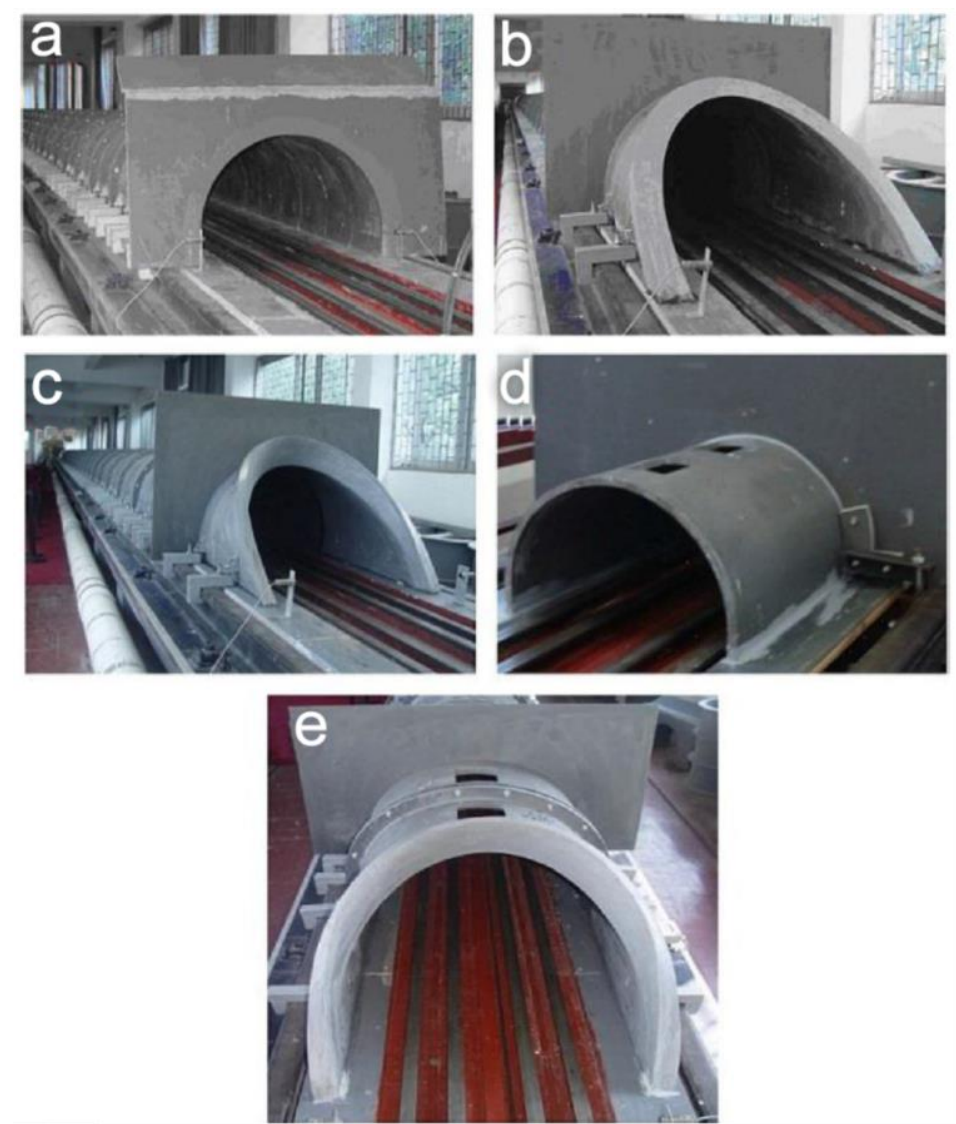

Şekil 5. Tünel portal modelleri: (a) duvar tip, (b) halka şekilli ve eğik yapıll, (c) şapka şekilli ve eğik yapılı, (d) üstü çift delikli düz şekilli (e) birleşik şapka eğik yapı [23]

Pencereli bir flüt yapısı için ilk sıkışma dalgası ve mikro basınç dalgası üzerindeki etkisi Howe $[24,43,44,45]$ tarafından incelenmiştir. Pencerelerin konum, sayı ve boyutlarının etkilerine ilişkin analizler detaylı olarak yapılmış; önerilen bazı değerler ve formüller ortaya konmuştur. Buna göre Mikro basınç dalgası, flütün pencereli yapısından önemli ölçüde etkilenir. Liu vd. [8] mikro basınç dalgasını azaltmak için pencereli eşit kesitli bir flüt ve aç-kapa önermişlerdir. Ayrıca aç-kapa uzunluğu ile pencere kesit alanı arasında makul bir eşleşme olduğunu bulmuşlardır. Heine vd. [25], şapka şekilli flüt yapısı ve tünel arasındaki konumlandırılan yalnızca bir havalandırma deliğinin tüneldeki basınç gradyanını azaltmak için en iyi yöntem olduğunu söylemektedir (Şekil 6). 


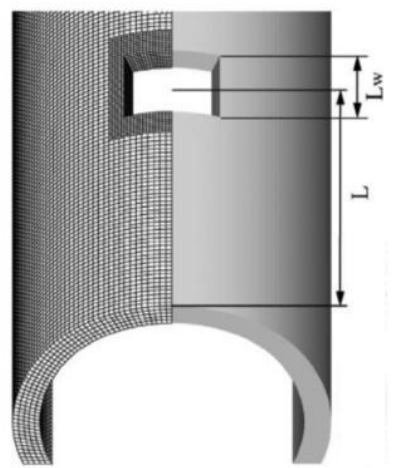

Şekil 6. Tünel giriş-çıkış (Flüt) yapısı ( $\mathrm{Lw}=0.057 \sim 0.514$, ve $\mathrm{L}=5 \sim 120 \mathrm{~m}$; [26])

Bitişik ve ayrı tünellerden geçen yüksek hızlı bir trenin aerodinamik etkileri: Birbirine yakın iki tünelin arasında boşluğun kapatılması veya açı olmasının aerodinamik etkilerinin araştırılması güzergâh tasarımı açısından son derece önemlidir. Li vd. [27] tarafından iki farklı tünel konfigürasyonunda (trenin bir boşlukla ayrılmış iki bitişik tünelden geçtiği, uzun bir tünelden geçtiği) analizler yapılmıştır. Bu çalışmada her iki senaryo arasında ciddi bir fark saptanmamıştır. Ancak aerodinamik sorunlarla uğraşırken, tünel acil kurtarma da dahil olmak üzere kapsamlı hususlar düşünülmesi gerektiği ve kısa tüneller için aerodinamik etkileri her tünelin kendi kritik tünel uzunluklarına göre değerlendirilmesi gerektiğini belirtmişlerdir.

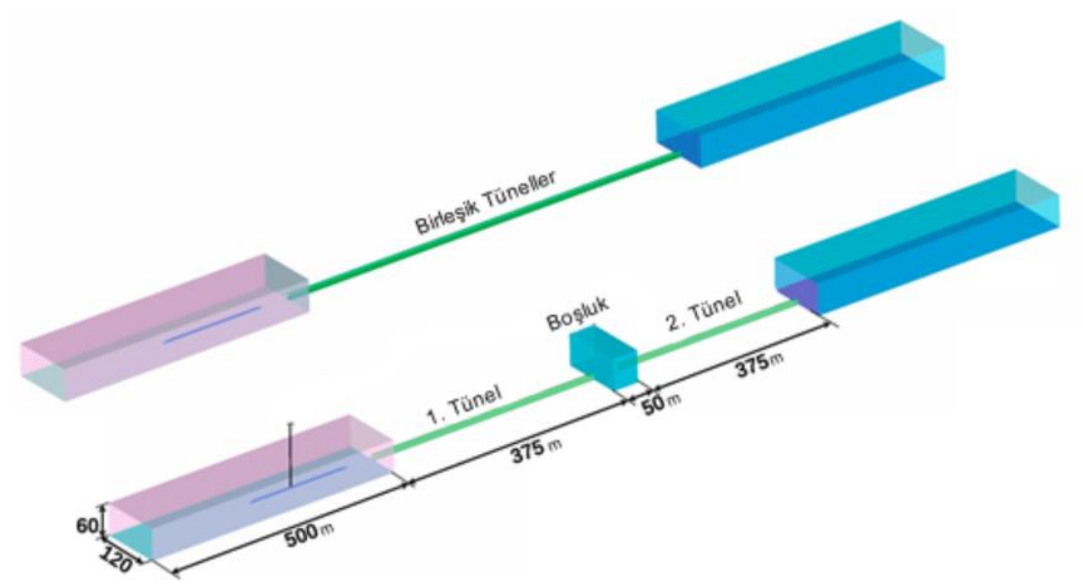

Şekil 7. Bağlantılı ve açık durumları diyagramı [27]

Yolcu kulağı rahatlı̆̆ı: Tünelden geçen hızlı trenlerin oluşturduğu basıncın insan kulağının hissetmeyeceği belirli bir genliği geçmemesi yolcu konforu açısından son derece önemlidir. $\mathrm{Bu}$ da yüksek hızlı bir demiryolu tasarımında, belirli bir zaman diliminde hava basıncının tekdüze değişimi, insan kulağının konfor kriterini belirlemek için geçici basıncın karakteristik parametresi olarak kullanılır. Geçici basınç konfor kriteri, yolculara tahsis edilmiş bir hat için tünel tasarımında önemli bir husustur ve aynı zamanda tünelin etkin boşluk alanını ve tren sızdırmazlığı gerekliliklerini belirlemenin temelidir [28].

1980'den 1985'e kadar, OREC149 Komitesi, tünellerden geçen yüksek hızlı bir trenin neden olduğu basıncın insan kulağı üzerindeki etkisi üzerine, hat testleri ve laboratuvar basınç odası testleri dahil olmak üzere bir dizi çalışma yürütmüştür. Bu çalışmaların sonucu olarak Şekil 8' deki grafik önerilmiştir. Buna karşın yüksek hızlı demiryolu çalışmalarında kullanılan kriterler ülkelere göre farklılık göstermektedir. İnsan kulağı konforunun farklı ülke ve bölgelerdeki değerlendirme indekslerinin analizine göre, genellikle değerlendirme indeksleri olarak basınç genliği, basınç gradyanı ve basıncın bir süre içindeki değişimi kullanılmaktadır (Tablo 2). 


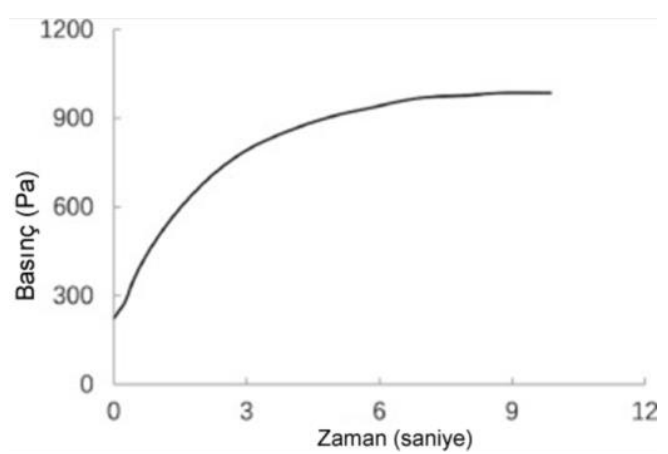

Şekil 8. İnsan kulağı konfor sınırı [8]

Tablo 2. Yüksek hızlı demiryolları için kulak zarı konfor kriterleri (Tek tip) [8]'den değiş̧tirilerek.

\begin{tabular}{|c|c|c|c|c|c|c|}
\hline \multirow[b]{2}{*}{ Ülke } & \multirow[b]{2}{*}{ Tren yolu } & \multicolumn{4}{|c|}{ Eşik değeri } & \multirow[b]{2}{*}{$\begin{array}{l}\text { Sızdırmazlık } \\
\text { özelliği }\end{array}$} \\
\hline & & $\begin{array}{c}\text { Genlik } \\
(\mathrm{kPa})\end{array}$ & $\begin{array}{c}\text { Gradyan } \\
(\mathrm{kPa} / \mathrm{s})\end{array}$ & $\begin{array}{c}\text { Basınç } \\
\text { değişimi } \\
(\mathrm{kPa})\end{array}$ & Zamanlar) & \\
\hline Japonya & Shinkansen & 1 & $0.20 .3 \sim 0.4$ & I & I & var \\
\hline İtalya & FS & 1,5 & 0,5 & I & l & var \\
\hline Güney Kore & KTX & I & I & $\begin{array}{c}0.8 \text { (Tek } \\
\text { hat tüneli) }\end{array}$ & 3 & var \\
\hline Çin & & & & $\begin{array}{c}\text { 1,25 (Çift } \\
\text { hatlı tek } \\
\text { tünel) }\end{array}$ & & var \\
\hline \multirow[t]{2}{*}{ İsviçre } & \multirow[t]{2}{*}{$\begin{array}{c}\text { Demiryolu } \\
2000\end{array}$} & / & l & 1,5 & 4 & var \\
\hline & & 0,5 & & & 1 & \multirow{3}{*}{ yok } \\
\hline \multirow[t]{3}{*}{ Almanya } & \multirow[t]{3}{*}{ Tek hat } & 0,8 & \multirow[t]{2}{*}{1} & & 3 & \\
\hline & & 1.0 & & \multicolumn{2}{|r|}{10} & \\
\hline & & 0,5 & \multirow{4}{*}{ / } & \multicolumn{2}{|r|}{1} & \multirow{4}{*}{ yok } \\
\hline \multirow{4}{*}{ UIC } & \multirow{4}{*}{$\begin{array}{l}\text { Tek ve çift } \\
\text { hatlar }\end{array}$} & 0,8 & & \multicolumn{2}{|r|}{3} & \\
\hline & & 1.0 & & \multicolumn{2}{|r|}{10} & \\
\hline & & 2.0 & & \multicolumn{2}{|r|}{60} & \\
\hline & & 1.0 & \multirow{4}{*}{ I } & & 1 & \multirow{4}{*}{ yok } \\
\hline \multirow{3}{*}{$\begin{array}{c}\text { ERRI } \\
\text { C218/RP1 }\end{array}$} & \multirow{3}{*}{$\begin{array}{c}\text { Tek ve çift } \\
\text { hatlar }\end{array}$} & 1,6 & & & 4 & \\
\hline & & 2.0 & & & 10 & \\
\hline & & 3.0 & & & 60 & \\
\hline
\end{tabular}

Tünel serbet alanı hesabı: Tünel içi serbest alan hesabı "International Union of Railways-UIC Code / 779 -11 [28]" da tanımlanmıştır. Tünel içi serbest alan hesabını etkileyen faktörler, Tünel içinde izin verilen maksimum hız, tünel boyu, tren boyu, tren alanıdır (tren alanı için ilgili yayında [28] 10-12 $\mathrm{m}^{2}$ arasında değer alınabileceği belirtilmektedir).

İzin verilen maksimum basınç değişimi: Trenin, tünel içinde izin verilen maksimum hızda giderken yaratacağı maksimum basınç değişiminin (pozitif ve negatif basınçların farkı olarak tanımlanır) $10 \mathrm{kPa}$ değerini aşmaması gerekir. Bu değer, 12.09.2002 tarihli Avrupa Birliği Resmî Gazetesi'nde "23.06.1996 tarihli Avrupa ülkeleri arası hızlı tren ağı işletmesi konsey yönergesine" atıfta bulunan 30.05.2002 tarihli konsey kararları içinde verilmiştir (Denklem 1).

$$
\Delta \mathrm{P}(\text { maksimum basınç değişimi })=5.0 \mathrm{kPa} / 4 \text { saniye }
$$


Tren kesit alanını bulmak için [28]'in arkasında verilen grafiklerden uygun trafik tipine, araç cinsine ve tünel içinde izin verilen maksimum hıza uygun olan grafik seçildikten sonra (Tünel boyu) / (Tren boyu) oranı ile tünel içinde izin verilen maksimum basınç değişimini grafik üzerinde kesiştiği noktaya göre "B: Tren alanı ile tünel içi serbest alan arasındaki oran" bulunur. Bu değer hesaplandıktan sonra tünel içinde kullanılacak olan trenin kesit alanı, bu değere bölünerek "tünel içi serbest alan" hesaplanmış olur.

\subsection{Tünellerde drenaj sistemleri ve sorunlar}

Tünellerde drenaj sorunlarının temeli kalsit yığışımları kökenlidir. Kalsit yığışımları, demiryolu tünellerinin drenaj sistemlerinde barbakanların ve su oluklarının tıkanmasına neden olarak, demiryolu hatlarında ve akabinde tren sirkülasyonunda ciddi problemler ortaya çıkartmaktadır. $\mathrm{Bu}$ sızıntıyı boşluk suyu basıncındaki artış hızlandırabilir ve bunun sonucunda tünel kaplamasında ciddi şekilde bozulma oluşabilir [29, 30].

Genel olarak, tünel tasarımında drenaj tipi belirlenirken tünel kaplaması üzerinde etkin boşluk suyu basıncı $(u)$ dikkate alınmaz, yani $u=0$ 'dır. Çünkü suyun drenaj sistemi aracılığıyla tünele akmasına izin verilir. Bununla birlikte, birincil kaplama üzerindeki su basıncı, drenaj işlevi ile doğrudan bağlantılıdır. Bu nedenle, drenaj düzgün çalışmadığı takdirde küçük bir miktar içeri su girişi durumunda bile, su basıncı beton kaplama yapısı üzerinde yıkıcı bir etki yapabilir [31].

Kalsiyum karbonatın çökelim mekanizması: Tünel drenaj sistemlerinde oluşan ana tortulaşma mekanizmasını Jung vd. [32] 3 farklı aşamada özetlemektedirler;

(1) Tünel içine akan noktasal olmayan kirlilik kaynağ $\left(\mathrm{CO}_{2}, \mathrm{NO}_{2}\right.$, araç egzoz gazının ana bileşeni $\mathrm{CO}, \mathrm{CO}_{2}, \mathrm{SO}_{3}, \mathrm{NO}_{2}$ vb. topraktaki mikrobiyal metabolik aktivitenin neden olduğu) su tarafından emilen tortuyu etkiler. Adsorbe edilen tortu elektrolit konsantrasyonunu değiştirir, ki bu tortunun birikmesine (kristalleşmeye) neden olan yapıştırıcı ve bağlayıcı görevi görür.

(2) Tünel içerisinden sızan yeraltı suyu ile beton yapılarda ayrıştırılan $\mathrm{Ca}(\mathrm{OH})_{2}$ toprakla birleşerek reaksiyona girer ve buna Puzolanik reaksiyon denir. Diğer bir deyişle, drenaj açıklığ içinde negatif (-) yüklü özelliklere sahip toprak parçacıklarının çoğundan oluşan kil ve $\mathrm{Ca}(\mathrm{OH})_{2}$ bileşenlerinin $\mathrm{Ca}_{2+}$ iyonu birbiriyle birleşerek bir kristal oluşturur (Şekil 9).

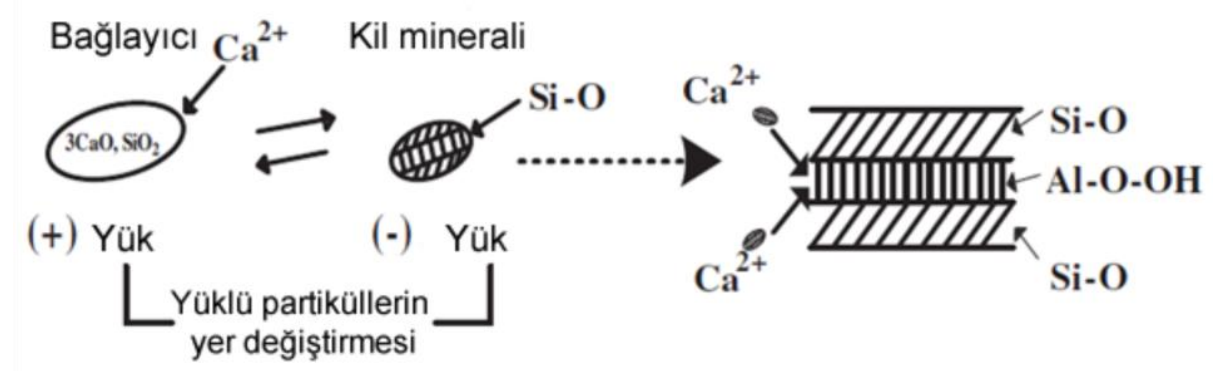

Şekil 9. Puzolanik reaksiyon [32]

(3) Toprak partiküllerinde adsorbe edilen suyun buharlaşması sonucu tortu kristalleşmeye (Kolloid $\rightarrow$ Kabalaşma) dönüşebilir. Kalsiyum karbonat oluşum süreci, Şekil 10'da gösterildiği gibi tünel drenaj açıklığında biriken tortuya neden olur. 


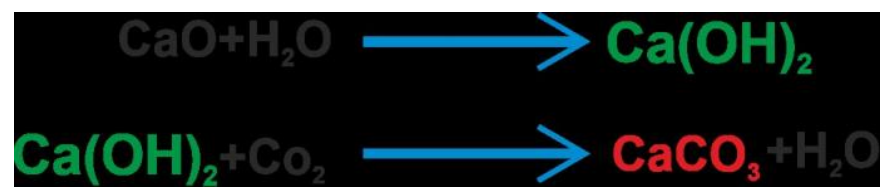

Şekil 10. Kalsiyum karbonat oluşumu [32]

Dünyadaki son teknoloji drenaj ve su geçirmezlik sistemleri: Bu bölümde, dünyadaki drenaj ve su geçirmezlik sistemlerinin son durumu hakkında kısa bir inceleme yapılarak kullanılan yeni yöntemler özetlenmeye çalışılmıştır. Avrupa'daki hızlı tren tünellerindeki drenaj sistemleri Gamisch ve Girmscheid [33]'e göre, tüneldeki su durumuna göre konumlandırılmıştır (Şekil 11).

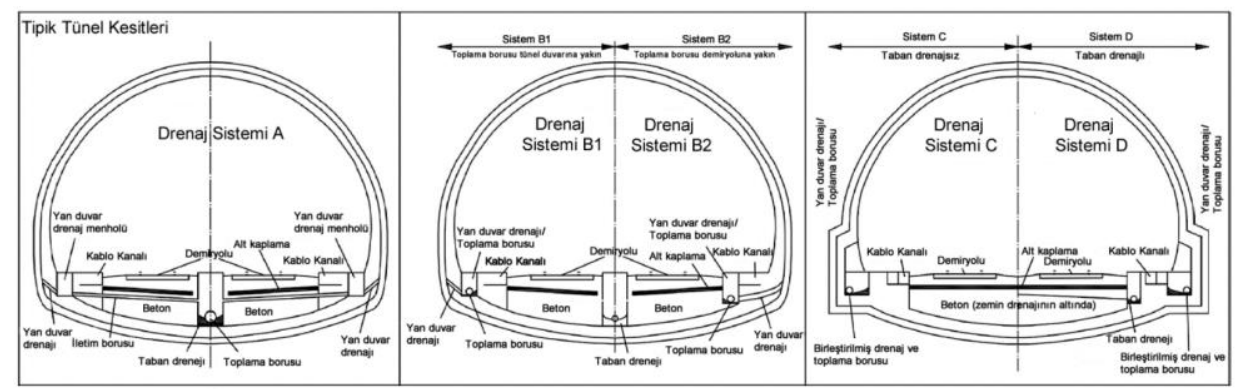

Şekil 11. Avrupa'daki bazı drenaj sistemleri (A; tünel tabanında ana drenaj borusu yer almaktadır. Su önce kenarlardaki drenaj borularına ardından enine borularla ana drenaj borusuna gelir. 88 metrede birde menhol bulunmaktadır. B tipinde orta drenaj ve yan drenajlar ayrıdır. C tipi orta drenaj yoktur. D tipi 2 yan drenaj içerir [33])

İsveç ve Norveç gibi kuzey Avrupa ülkelerinde sağlam kaya tünelleri bulunmaktadır. Kaya tünellerinde tek kat kaplama yaygın olarak uygulanır. Kaya tünellerinin su geçirmezlik ve drenaj sistemleri püskürtme beton ve bulondan oluşur. Farklı türde çelik bağlantı parçaları ile köpüklü bir polietilen kaplama monte edilerek püskürtme betonla kaplanır (Şekil 12). Su, şilteler üzerinde toplanır ve tünelin altındaki drenaj boruları ile tünelden dışarı yönlendirilir.

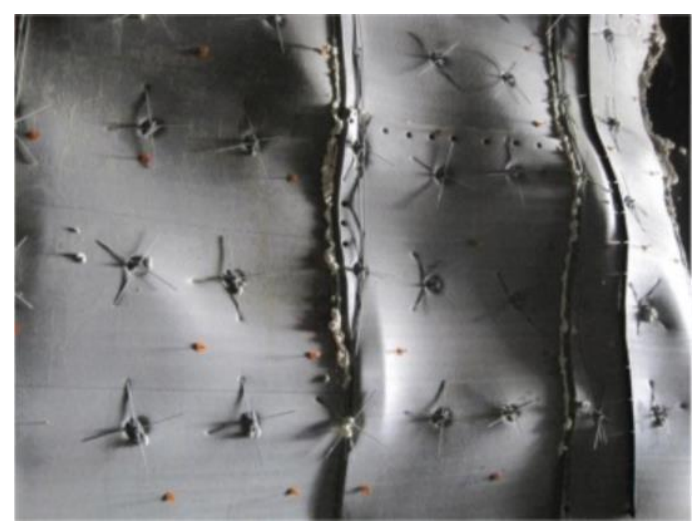

Şekil 12. Monte edilmiş standart drenaj matı [34]

Japonya, Güney Kore ve Çin'deki çoğu tünelde uygulanan drenaj sistemi neredeyse birbiriyle aynıdır. Nihai kaplamanın arkasındaki su basıncını azaltmak için su boşaltılır. Su yalıtımı, membranın arkasında olduğu jeotekstil veya geokompozit bir tabaka ile sağlanır. Ek olarak bazı durumlarda su, yan duvar tahliye boruları vasitası ile toplanıp enine borular vasıtasıla tünelin orta tabanındaki ana tahliye borusuna iletilmektedir. Ana gider hariç bu boruların üst kısımları deliklidir. Drenaj sistemi ise, boyuna drenaj borusu, dairesel drenaj borusu, merkezi drenaj kanalı, menhollerle oluşturulmaktadır. Buradaki ana unsur, merkezi drenaj kanalının ayarlandığı konumdur (Şekil 15). 

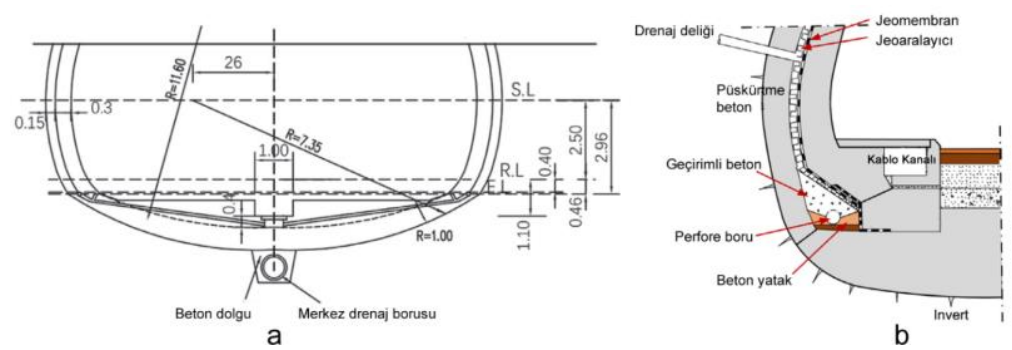

Şekil 13. Japonya ve Güney Kore'de kullanılan tünel içi drenaj tipleri (a: Japonya, tünel tabanı drenaj kanalı [35]; b: Güney Kore, Birincil kaplama ile nihai kaplama arası geokompozit, membran ve tünel arkası su toplama borularının birlikte kullanımı; [48])

\section{Türkiye'de YHT Tünelleri}

2003 yılındaki adıyla Devlet Limanlar Havayolları Genel Müdürlüğü (DLH) tarafından proje genel esasları belirlenen ve sonrasında yayımlanan [49] Yüksek Hızlı Demiryolu (YHT) çalışmalarına yine aynı yıl Ankara-İstanbul YHT projelendirme çalışmaları ile başlanmıştır. Tünel kesiti olarak çift hatlı tek tüp tünel kesiti benimsenmiş, $85 \mathrm{~m}^{2}$ minimum serbest alan olacak şekilde tünel boyutlandırılmıştır (12,5 m genişliğinde 7,5 m yüksekliğinde). O tarihten itibaren projelendirme çalışmaları bu esaslara göre ilerlemiştir. Günümüzde YHT proje ve imalat çalışmaları TCDD (Türkiye Cumhuriyeti Devlet Demiryolları) ve AYGM (Alt Yapı Yatırımları Genel Müdürlügü) tarafından yürütülmektedir. İşletmeye 99,63 km tünel açılsa da farklı hatlarda $132,18 \mathrm{~km}$ tünel imalatı tamamlanmış 79,44 km tünel imalatı da devam etmektedir. 2003 yılında belirlenen tünel tasarımı neredeyse hiç değiştirilmeden $180 \mathrm{~m}$ uzunluktan $9700 \mathrm{~m}$ uzunluğa kadar tüm YHT tünellerinde uygulanmış veya uygulanmaya devam etmektedir (Şekil 14a). Tünel ve yolcu güvenliğinin YHT hatlarında sağlanması amacı ile UIC tarafından 2008 yılında yayımlanan Tünel güvenlik [4] standart belgesinin ardından Ankara-İstanbul YHT projesinde 2013 yılında ilk kez acil durum müdahalesi de düşünülerek $5 \mathrm{~m}$ yükseklikte ve $4,5 \mathrm{~m}$ genişlikte tünel kesiti planlanmış ve o tarihten itibaren, tamamlanan ve yapım aşamasında olan tüm ana hat YHT (Ankara-İstanbul; Bursa-Osmaneli; Ankara-Sivas; Ankara-İzmir) tünellerinde bu kesit kullanıma başlanmıştır. (Şekil 14b).
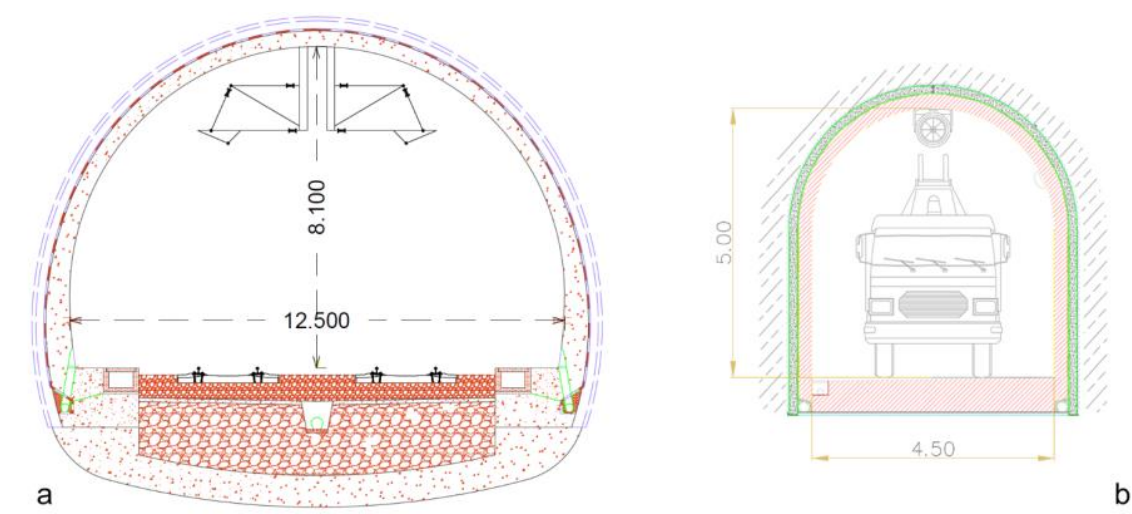

Şekil 14. Yüksek hızlı demiryollarında uygulanan tünel tip kesitleri (a: çift hatlı tek tüp ana hat tüneli [50], b: güvenlik tüneli [51])

Türkiye'deki YHT tünellerinde uygulanan tünel içi drenaj sistemleri dünyadaki uygulamalar özellikle Japonya ile paralellik göstermektedir. Tünellerin geçtiği jeolojik birimlerin geçirgenlik özelliklerinin değişkenliği nedeniyle tünellerdeki su durumuna göre farklı planlamalar yapılmaktadır. Buradaki temel farklılık taban altı drenaj sistemi ve bu sistemin yan drenaj sistemi ile bağlantısıdır. Tünel içine su geliş miktarına göre taban drenaj çapı, menhol ve yan drenaj bağlantı sıklığı arttırılmaktadır (Şekil 15). 


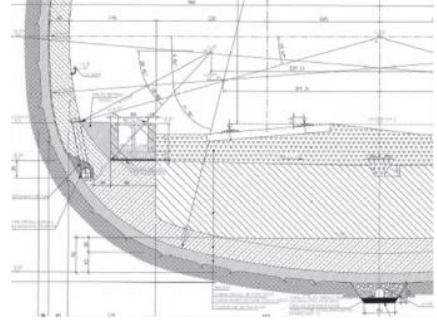

a

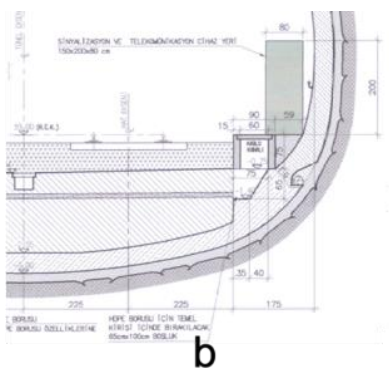

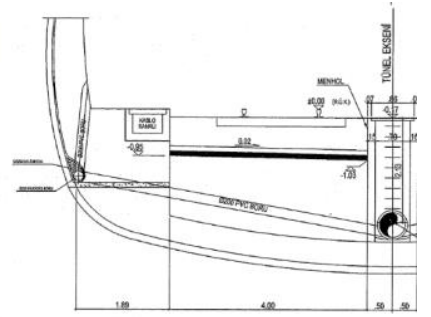

C

Şekil 15. Yüksek hızlı demiryolu tünellerinde kullanılan drenaj tipleri (a tünel tabanı altı drenajı, b: sadece tünel kaplama arkası drenajı, c: tünel taban drenaj ve menhollü; [52])

Ülkemizdeki YHT Tünellerinde giriş çıkış yapısı olarak (flüt yapısı) 2 farklı tip kullanılmaktadır. Bunlar düz $45^{\circ}$ ve $33^{\circ}$ eğimde yapılardır. (Şekil 16). Tünel içlerinde $1,25 \mathrm{~m}$ genişliğinde $2,25 \mathrm{~m}$ yüksekliğinde kablo kanalı üzerinde yürüme yolu ve her $750 \mathrm{~m}$ bir $20 \mathrm{~m}$ genişliğinde cep bölgesi oluşturulmuştur.

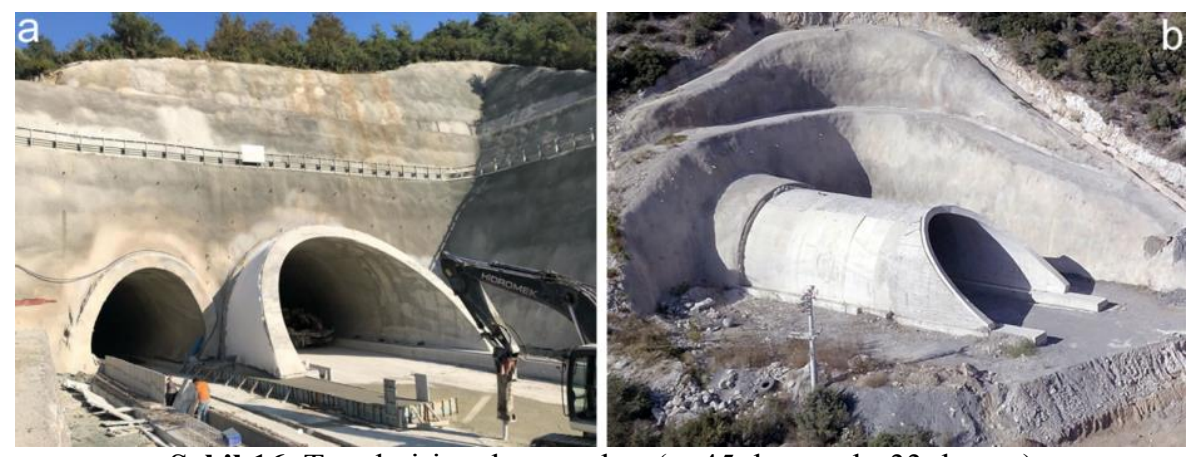

Şekil 16. Tünel giriş-çıkış yapıları (a: 45 derece; b: 33 derece)

\section{YHT Tünellerinde Yaşanan Sorunlar}

Türkiye'de demiryolu serüveni 1866 y1lında İzmir-Aydın demiryolu ile başlasa da modern anlamda ilk YHT tüneli Ankara-Eskiş̧ehir hattında yer alan ve 2006 yılında tamamlanan 471 metrelik Duatepe (Kartaltepe) tünelidir. Ardından Ankara-Konya ve Köseköy-Gebze arasında 31 farklı tünel (yaklaşık $46 \mathrm{~km}$ ) işletmeciliğe açılmıştır. 2008 yılından günümüze işletmecilik faaliyetleri yürütülen tünellerde sorumlu personelin gayretleri ve alınan tedbirler ile herhangi bir sorun oluşmasına müsaade edilmese de tünel içi drenaj sorunları yaşandığı rapor edilmiştir.

\subsection{Tünel içi yapısal sorunlar}

Tünel içi yapısal sorunların başında tünel girişlerinde yaşanan kısa süreli ve ani sarsıntı ve basınç artışları gelmektedir. Kısa süreli oluşan basınç farklılığı özellikle küçük yolcular tarafından hissedilmektedir. Bir diğer yapısal sorun ise kablo kanallarının konumudur. Kablo kanallarının konumu, yüksekliği ve kapak tasarımı sonucunda bakım sorunlarının oluştuğu bilinmektedir. Kablo kanalları tünel kenarında drenaj kontrol bacalarının yanında bulunmaktadır. Bu konum sonucu drenaj sorunu olan tünellerde kablo kanalının içerisi su dolmaktadır. Bir diğer konu ise kablo kanal kapaklarının tipleridir. Ülkemizde ve dünyada farklı tip kapaklar kullanılmaktadır. Ortası boşluklu (Şekil 17a) tip kablo kanallarında ince yapıldığında kırılmalar kalın yapıldığında da bakım sırasında kapağı kaldırmakta sorunlar yaşanmaktadır. Demir tutamaklı kanallarda ise tutamaklarla ilgili sorunlar olmakta zaman zaman kablo kapağı tutamak bağlantı noktalarında ve kapak kenarlarında kırılmalar gözlemlenmektedir (Şekil 17b). 


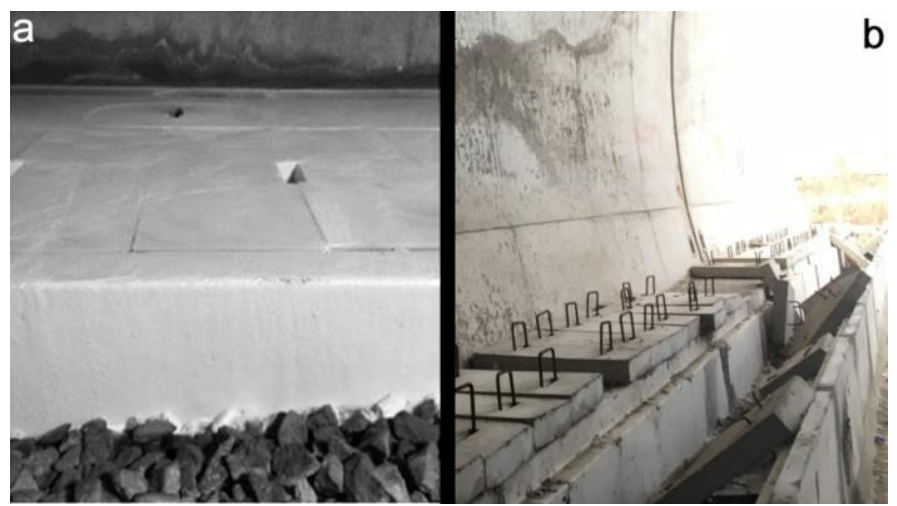

Şekil 17. Tünel içi kablo kanalı kapak tipleri (a: iç tutamaklı, b: demir tutamaklı)

\subsection{Tünel içi drenaj sorunları}

Tünel içi drenaj sorunlarının başında tünel içi kontrol bacalarından sızan sular gelmektedir. Yüksek hızlı demiryollarında uygulanan \%o16 maksimum eğim suyun akışını sağlasa da çakıl, beton parçası, inşat atığ 1 vb. yabancı maddeler akışı engellemekte, zamanla kalsit çökelmelerinin de etkisiyle tıkanıklıklar oluşmaktadır. Tıkanan noktalarda su kontrol bacasından taşmakta tünel eğimi boyunca birkaç ano katettikten sonra ano birleşim noktalarından tekrar tünel içerisinde kaybolmaktadır. Özellikle suların kontrol bacasından çıkışı sırasında su içerisinde çözünmüş halde bulunan kalsiyum karbonat gibi eriyik haldeki çözeltiler tünel içerisine çökelmektedir. T1kanıklığın bulunduğu noktalarda bakım ekipleri su jeti ve çeşitli kimyasallar kullanarak tıkanıklığı açmaktadır.

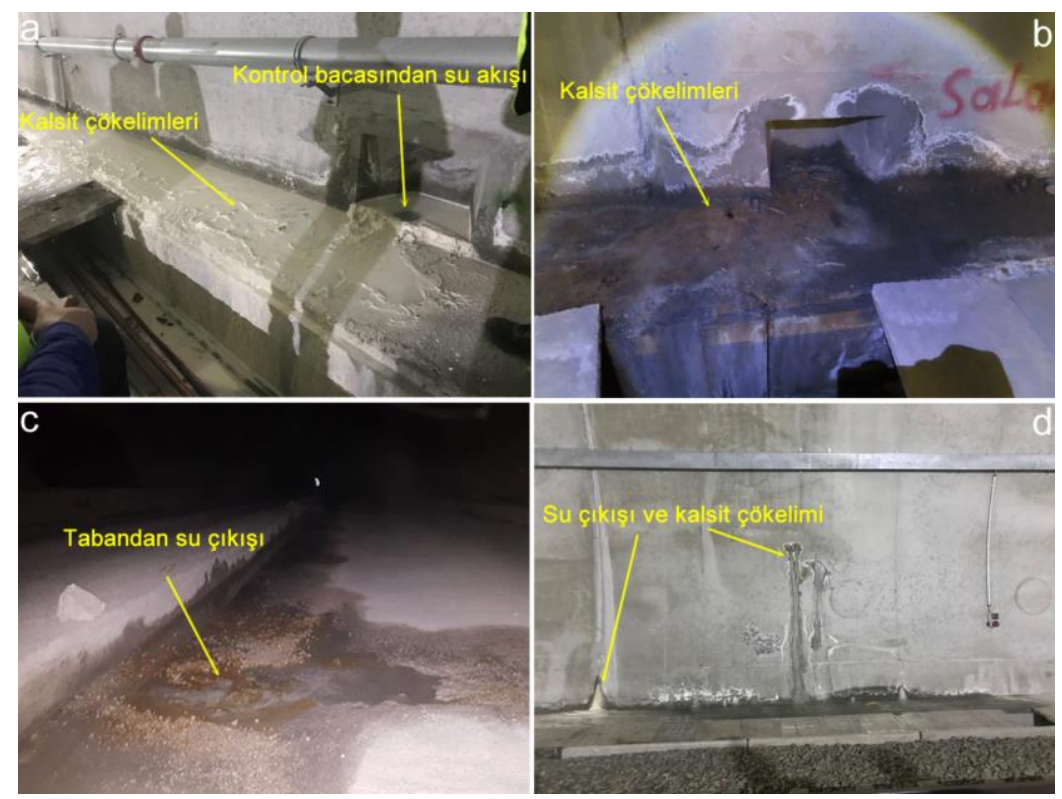

Şekil 18. Tünel içi drenaj sorunları (a: beyaz renkli kalsit çökelimi; b: siyah renkli kalsit çökelimi; c: tünel tabanından su gelişi; d: tünel duvarından su gelişi ve kalsit çökelimi)

\section{Sonuç ve Öneriler}

Bu çalışmada, 20 yıldır dizaynı neredeyse hiç değişmeyen tek tüp, çift hatlı yüksek hızlı demiryolu tünellerinin dizaynına odaklanılmıştır. Bundaki temel gaye dünyada yaşanan son gelişmeler ve ülkemizde işletmecilik sırasında edinilen tecrübeler ile gelecekte yapılması planlanan projeler için önerilerde bulunmaktır. Bu kapsamda; 
1- 1000 metreden uzun tünellerde güvenlik tüneli oluşturulmas1 5000 metreden uzun tünellerin tek hatlı çift tünel olarak planlanması tünel emniyeti açısından önerilmektedir. Ek olarak planlanan tünellerin güvenliğinin oluşturulabilmesi için UIC ve TSI standartlarında belirtilen özelliklere ek olarak her tünel araçla müdahale durumuna göre değerlendirilmelidir.

2- Demiryolu tünellerindeki aerodinamik etkileri azaltmak için kullanılacak araçlarda ve halihazırda ülkemizde tasarım-imalat aşamasında olan hızlı ve yüksek hızlı yük-yolcu araçlarında burun yapılarında hava akımına müsaade eden ve minimum 2 metre uzunluğunda bir yapının tercih edilmeli, tren arka yapılarında ise küt bir tasarım yerine akıcı (kavisli) bir yap1 tercih edilmelidir.

3- Tünellerin giriş-çıkış yapılarında mikro basınç dalgalarına karşı oluşturulan yapılarda ülkemizde uygulanan düz-eğimli yapılar yerine farklı araştırmacılar tarafından verimliliği kanıtlanmış $33^{\circ}$ eğimli şapka şekilli ve tepe noktasında tek pencereli yapılar kullanılmalıdır.

4- Tünel şekli ve genişliği maliyeti doğrudan etkileyen en önemli parametredir. Dolayısıyla optimum tünel şeklinin ve genişliğinin belirlenmesi çok önemlidir. Tünel şeklinin ve genişliğinin belirlenmesi amacı ile UIC CODE 779-11 [28]'de tariflenen serbest alan hesabı kullanılmaktadır. Bu standartta temel alınan değer yolcu kulağı rahatlığıdır. Standartta belirtilen değerlerle birlikte kulağa uygulanan basınç değeri birbirinden bağımsız birçok farklı parametreye bağlıdır. Örneğin hava geçirgenliği düşük olan bir tren ile nispeten hava geçiren bir trende hissedilen değerler artmaktadır. Tünel içerisinde hava akımı şiddeti ve yönü de kulak rahatlığını etkilemektedir. Yine benzer şekilde tünelde havalandırma şaftının olması, acil kaçış ya da yaklaşım tünelinin olması gibi durumlarda kulak rahatlığını etkilemektedir. Dolayısıyla her tünel kendi özel koşullarına göre değerlendirilmelidir. Bir diğer önemli husus ise iki trenin tünel içerisinde karşılaştığı durumlardır. Böyle durumlarda trenlerin birbirine olan mesafesinden daha çok trenin tünel duvarına olan mesafesi önem kazanmaktadır. $\mathrm{Bu}$ noktada tren ile duvar arasındaki boşluk mümkün olduğunca arttırılmalıdır. Birbirine çok yakın tünellerin ayrı ya da birleşik olmasının aerodinamik açıdan bir farklılık oluşturmadığı anlaşı1mıştır. Ancak böyle durumlarda acil kaçış ve müdahale durumları da değerlendirilerek iki tünel arasının açık bırakılması maliyet etkin bir çözüm olmaktadır.

5- Ülkemizdeki tünel içi drenaj sisteminde kullanılan boru tip ve yerleşim planları dünyadaki uygulamalar ile paralellik göstermektedir. Tünelde yaşanan drenaj sorunları da yine dünyada yaşanan sorunlarla paraleldir. Öncelikle halen tünelin bir kısmı için kullanılan su tutucu mat (membran) tüm tüneli kapsayacak şekilde (tünel tabanına) uygulanması gerekmektedir. Klasik su tutucu mat imalatı çift katlı kaynak ile yapılmakta ve dikkatli işçilik gerektirmektedir. İmalat sırasında oluşabilecek sorunlarını gidermek için likit (sürülebilir) drenaj matları tercih edilebilir.

6- Tünelde birincil kaplama ile ikincil kaplama arasında kullanılan Tünel Tipi PVC drenaj borusunun [36] tıkanmasını önlemek amacı ile düz ve delikli boru tipine geçilmesi gerekmektedir. Ayrica su gelişi beklenen tünellerde Şekil 11-d'de gösterilen drenaj kanal tip kesitleri kullanılmalıdır.

7- Tünellerde sorun yaratan bir diğer konu ise kablo kanallarının konumu ve kapaklarıdır. Yaya yürüme yolu olarak da kullanılan bu yapılar zaman zaman kırılmakta veya bakım sırasında bakım yapan personele kaldırıp indirmekte zorluk oluşturmaktadır. Bu noktada kablo kanalının konumu tünel yan duvarı içerisine alınarak çözülebilir.

Yukarıda derlenmeye çalışılan bilgiler çerçevesinde yaklaşık 20 yıldır değişmeden yüksek hızlı demiryolu tünel kesitinde ve giriş-çıkış yapısında yapısal ve geometrik iyileştirmeler gerektiği, ek olarak açlacak olan tünelin uzunluğu, çevresiyle olan ilişkisi, hava akımı durumu, tünel içi 
havalandırma bacası, yaklaşım tüneli içermesi durumlarına göre tünellerin ayrı ayrı değerlendirilmesi gerektiği sonucuna varılmıştır.

\section{Teşekkür}

Yazar bu çalışma kapsamında TCDD yetkili personeline göstermiş oldukları yardım ve desteklerinden dolayı teşekkür eder.

\section{Kaynakça}

[1] Concerning the technical specification of interoperability relating to 'safety in railway tunnels' in the trans-European conventional and high-speed rail system, TSI, 2008/163/EC, 2008.

[2] D. Diamantidis, F. Zuccarellib, A. Westha, "Safety of long railway tunnels," Reliability Engineering and System Safety, 67, 135-145, 2000.

[3] E. Poşluk, M. Korkanç, "Yüksek Hızlı Demiryolu Tünellerinde Güvenlik Tüneli Modellemeleri: Ankara-İstanbul Hızlı Tren Projesi 26 Numaralı Tünel Örneği," Ömer Halisdemir Üniversitesi Mühendislik Bilimleri Dergisi, 6/2, 642-652, 2017.

[4] Safety in railway tunnels, UIC Code 779-9, 2003.

[5] Railway applications. The specification and demonstration of reliability, availability, maintainability and safety (RAMS), BS EN 50126, England, 1999.

[6] J.A. Schetz, "Aerodynamics of high-speed trains," Annu. Rev. Fluid Mech. 33 (1) 371-414, 2001.

[7] C.J. Baker, "A review of train aerodynamics Part 1-Fundamentals," Aeronaut. J. 118 (1201) 201-228, 2014.

[8] J. Niu, Y. Sui, Q. Yu, X. Cao, Y. Yuan, "Aerodynamics of railway train/tunnel system: A review of recent research," Energy and Built Environment, 1(4), 351-375, 2020.

[9] P. Xue, S. You, J. Chao, T. Ye, "Numerical investigation of unsteady airflow in sub- way influenced by piston effect based on dynamic mesh," Tunnelling and Underground Space Technology, 40 174$181,2014$.

[10] T. Moreno, N. Pérez, C. Reche, V. Martins, E. de Miguel, M. Capdevila, S. Centelles, M.C. Minguillón, F. Amato, A. Alastuey, X. Querol, W. Gibbons, "Subway platform air quality: assessing the influences of tunnel ventilation, train piston effect and station design," Atmos. Environ., 92 461-468, 2014.

[11]M. Juraeva, J.H. Lee, D.J. Song, "A computational analysis of the train-wind to identify the best position for the air-curtain installation," J. Wind Eng. Ind. Aerodyn., 99 (5) 554-559, 2011.

[12] M. Fu, P. Li, X.F. Liang, "Numerical analysis of the slipstream development around a high-speed train in a double-track tunnel," PLOS ONE, 12 (3) e0175044, 2017.

[13] A. Khayrullina, B. Blocken, W. Janssen, J. Straathof, "CFD simulation of train aero- dynamics: traininduced wind conditions at an underground railroad passenger platform," J. Wind Eng. Ind. Aerodyn. 139 100-110, 2015.

[14]M. Rabani, A.K. Faghih, "Numerical analysis of air flow around a passenger train entering the tunnel," Tunnelling and Underground Space Technology, 45 203-213, 2015.

[15]Y.C. Ku, J.H. Rho, S.H. Yun, M.H. Kwak, K.H. Kim, H.B. Kwon, D.H. Lee, "Optimal cross-sectional area distribution of a high-speed train nose to minimize the tunnel micro-pressure wave," Struct. Multidiscipl. Optim. 42 (6), 965-976, 2010.

[16] J.K. Choi, K.H. Kim, "Effects of nose shape and tunnel cross-sectional area on aero- dynamic drag of train traveling in tunnels," Tunnelling and Underground Space Technology, 41, 62-73, 2014.

[17] M. Suzuki, "Unsteady aerodynamic force acting on high speed trains in tunnel," Q. Rep. RTRI 42 (2) 89-93, 2001.

[18] T. Miyachi, T. Fukuda, S. Saito, "Model experiment and analysis of pressure waves emitted from portals of a tunnel with a branch," J. Sound Vib. 333 (23), 6156-6169, 2014.

[19] A. Baron, M. Mossi, S. Sibilla, "The alleviation of the aerodynamic drag and wave effects of highspeed trains in very long tunnels," J. Wind Eng. Ind. Aerodyn., 89 (5), 365-401, 2001.

[20]F. Liu, S. Yao, J. Zhang, Y.B. Zhang, "Effect of increased linings on micro-pressure waves in a highspeed railway tunnel," Tunnelling and Underground Space Technology, 52, 62-70, 2016.

[21] K. Kikuchi, M. Iida, T. Fukuda, "Optimization of train nose shape for reducing mi- cro-pressure wave radiated from tunnel exit," J. Low Frequency Noi. Vibrat. Act. Control, 30 (1), 1-19, 2011.

[22] M. Iida, T. Matsumura, K. Nakatani, T. Fukuda, T. Maeda, "Effective nose shape for reducing tunnel sonic boom," QR of RTRI, 38 (4), 206-211, 1997. 
[23]L. Zhang, M.Z. Yang, X.F. Liang, J. Zhang, "Oblique tunnel portal effects on train and tunnel aerodynamics based on moving model tests," J. Wind Eng. Ind. Aerodyn., 167, 128-139, 2017.

[24] M.S. Howe, "The genetically optimized tunnel-entrance hood," J. Fluids Struct., 23 (8), 1231-1250, 2007.

[25] D. Heine, K. Ehrenfried, G. Heine, S. Huntgeburth, "Experimental and theoretical study of the pressure wave generation in railway tunnels with vented tunnel portals," J. Wind Eng. Ind. Aerodyn., 176, 290300,2018

[26] X. Xiang, L. Xue, B. Wang, W. Zou, "Mechanism and capability of ventilation open- ings for alleviating micro-pressure waves emitted from high-speed railway tunnels," Build. Environ., 132 245254, 2018.

[27] W. Li, T. Liu, P. Martinez-Vazquez, Z. Chen, Z. Guo, M. Li, H. Liu, “Aerodynamic effects of a highspeed train travelling through adjoining \& separated tunnels," Tunnelling and Underground Space Technology, 113, 103-973, 2021.

[28] Determination of railway tunnel cross-sectional areas on the basis of aerodynamic considerations, UIC code 779-11, 2005,

[29] L.N. Reddi, X. Ming, M.G. Hajra, I.M. Lee, "Permeability reduction of soil filters due to physical clogging," Journal of Geotechnical and Geoenvironmental Engineering, 126 (3), 236-246, 2000.

[30] J.H. Shin, T.I. Addenbrooke, D.M. Potts, "A numerical study of the effect of groundwater movement on long-term tunnel behaviour," Geotechnique, 52 (6), 391-403, 2002.

[31]C. Oggeri, G. Ova, "Quality in tunnelling," Tunnelling and underground space technology, 19, 34, 2004.

[32] H.S. Jung, Y.S. Han, S.R. Chung, Chun, B.S., Lee, Y.J., "Evaluation of advanced drainage treatment for old tunnel drainage system in Korea," Tunnelling and underground space technology, 38, 476-486, 2013..

[33] T. Gamisch, G. Girmscheid, "Future trends in construction and maintenance management of drainage systems in traffic tunnels," Tunnelling Towards Better Cities, 5-2, 2005.

[34]H. Stripple, L. Bostrom, T. Ellison, C. Ewertson, P. Lund, R. Melander, "Evaluation of two different drainage systems for rock tunnels," Tunnelling and Underground Space Technology, 58, 40-48, 2016.

[35] CARS, "Report on the Railway Tunnel Drainage Techniques," Tech. rep. China Academy of Railway Sciences, Beijing (Chinese), 2016.

[36] DIN 4262-1: 2009-10, "Rohre und Formstücke für die unterirdische Entwässerung im Verkehrswegeund Tiefbau - Teil 1: Rohre, Formstücke und deren Verbindungen aus, PVC-U, PP und PE, 2009.

[37] C.J. Baker, “A review of train aerodynamics Part 2-Applications," Aeronaut. J. 118 (1202), 345-382, 2014.

[38] J.Y. Kim, K.Y. Kim, "Effects of vent shaft location on the ventilation performance in a subway tunnel," J. Wind Eng. Ind. Aerodyn. 97 (5), 174-179, 2009.

[39] M. Juraeva, J.H. Lee, D.J. Song, "A computational analysis of the train-wind to identify the best position for the air-curtain installation,” J. Wind Eng. Ind. Aerodyn, 99 (5), 554-559,2011.

[40] [40] Y.D. Huang, L.I. Chan, N.K. Chang, "A numerical analysis of the ventilation perfor- mance for different ventilation strategies in a subway tunnel," J. Hydrodyn. Ser. B 24 (2), 193-201, 2012.

[41]C.R. Chu, S.Y. Chien, C.Y. Wang, T.R. Wu, "Numerical simulation of two trains intersecting in a tunnel," Tunnelling and Underground Space Technology, 42, 161-174, 2014.

[42] B. Diedrichs, S. Krajnovi, M. Berg, "On The Aerodynamics Of Car Body Vibrations Of High-Speed Trains Cruising İnside Tunnels,” Eng. Appl. Comput. Fluid Mech. 2 (1) 51-75, 2008.

[43] M.S. Howe, M. Iida, T. Fukuda, T. Maeda, "Theoretical And Experimental İnvestiga- Tion Of The Compression Wave Generated By A Train Entering A Tunnel With A Flared Portal," J Fluid Mech 425, 111-132, 2000.

[44] M.S. Howe, M. Iida, T. Fukuda, "Influence of an unvented tunnel entrance hood on the compression wave generated by a high-speed train," J. Fluids Struct. 17 (6) 833-853, 2003.

[45] M.S. Howe, A. Winslow, M. Iida, T. Fukuda, "Rapid calculation of the compression wave generated by a train entering a tunnel with a vented hood: short hoods," J. Sound Vib., 311 (1-2), 254-268, 2008.

[46] M. Suzuki, Flow-induced vibration of high-speed trains in tunnels, The Aerodynamics of Heavy Vehicles: Trucks, Buses, and Trains, Heidelberg: Springer, 2004.

[47] J. Lee, J. Kim, “Approximate optimization of high-speed train nose shape for reduc- ing micropressure wave," Struct. Multidiscipl. Optim. 35 (1) 79-87, 2008.

[48]D. Kolymbas, Tunnelling and Tunnel Mechanics A Rational Approach to Tunnelling, Heidelberg: Springer, 2005. 
[49]P. Yüksel, "Demiryolları Planlama ve Tasarım Teknik Esasları," Demiryolları, Limanlar, Havameydanları İnşaatı Genel Müdürlüğü, Ankara: 2007.

[50] Yüksel Proje Uluslararası A.Ş., "Ankara- İstanbul Hızlı Tren Projesi Tünel Destek Paftaları," Yayımlanmamış, 2013.

[51] O. Şimşek, E.B. Aygar, A. Ertin, “Ankara- İstanbul Hızlı Tren Projesi Güvenlik Tünelleri Paftaları,” SİAL Yer Bilimleri Ltd. Şti., Yayımlanmamış, 2009.

[52] O., Şimşek, E.B. Aygar, "Bursa-Yenişehir Yüksek Hızlı Tren Projesi Drenaj Paftaları,” Fugro-SİAL Yer Bilimleri Ltd. Şti., Yayımlanmamış, 2014.

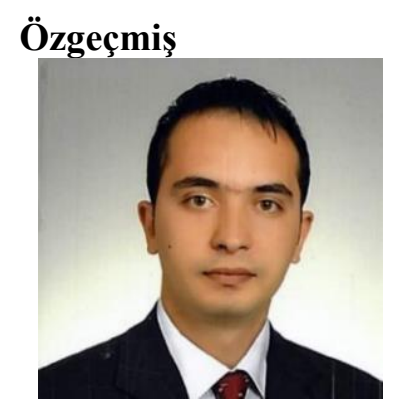

\section{Evren POŞLUK}

1981 yılında Niğde'de doğmuştur. Lisans ve yüksek lisans eğitimini Karadeniz Teknik Üniversitesinde tamamlamıştır. Halen TCDD 1. Bölge Müdürlügü̈'nde çalışmakta olup İstanbul ÜniversitesiCerrahpaşa Jeoloji Mühendisliği Anabilim Dalında doktora öğrenimine devam etmektedir.

Beyanlar:

E-Posta: evrenposluk@gmail.com

$\mathrm{Bu}$ makalede bilimsel araştırma ve yayın etiğine uyulmuştur. 